\title{
SUBSTANCE P IN THE CENTRAL NERVOUS SYSTEM \\ OF RABBITS : UPTAKE SYSTEM DIFFERS FROM PUTATIVE TRANSMITTERS
}

\author{
Tomio SEGAWA, Yoshihiro NAKATA, Kimiko NAKAMURA, \\ Haruaki YAJIMA* and Kouki KITAGAWA* \\ Department of Pharmacology, Institute of Pharmacentical Sciences, Hiroshima \\ University School of Medicine, Kasumi 1-2-3, Hiroshima 734, and \\ * Department of Manufacturing Chemistry, Faculty of Pharmaceutical Sciences, \\ Kyoto University, Sakyo-ku, Kyoto 606, Japan
}

Accepted July 12, 1976

Neurophysiological and neurochemical data have suggested that substance $\mathbf{P}$ may function as a neurotransmitter at synapses in the central nervous system, particularly in primary sensory neurons $(1,2)$. Mechanisms responsible for terminating the action of substance $P$ at the synapse are however, unknown. Benuck and Marks (3) have partially purified the enzyme responsible for inactivation of substance $P$ in rat brain. However, extensive research with the biogenic amines has suggested that enzymatic inactivation of a neurotransmitter is an exception rather than the rule (4). Several putative transmitters are taken up into nerve terminals through a specific high affinity uptake system which appears to account for their inactivation process. Although presence of a high affinity uptake system is not a criterion necessary for transmitter identification, such would greatly favor the candidacy of a compound for the transmitter (4).

A bovine hypothalamus substance P, Arg-Pro-Lys-Pro-Gln-Gln-Phe-Phe-Gly-Leu-Met, was synthesized by the conventional method described in a previous paper (5). The synthetic substance $P$ was labelled with tritium by a catalysed gas-exposure method, using platinum as the catalyst $(6,7)$. To remove the catalyst, unstable generally labelled compounds, labile tritium and tritiated impurities which arise during irradiation, the irradiated substance $P$ was lyophilized eight times. The purity of the labelled compound was checked as follows: 1) When the compound was dansylated by the method of Gray and Harlley (8) and was submitted to thin layer chromatography of silica gel, a single spot was observed. Furthermore, the spot coincided with the peak of radiochemical activity determined by a scan of thin layer chromatogram. 2) The biological activity on guinea pig ileum was approximately $80 \%$ of that of the parent compound. 3) A mixture of an aliquot of labelled and parent substance $P$ was submitted to gel chromatography using a Sephadex G-15 column. When the column was screened for both guinea-pig ileum contracting activity and radioactivity the patterns of both were similar. These results indicated that the labelled substance $\mathrm{P}$ was of high purity. The compound is a powder, with a specific activity of $1.31 \mathrm{Ci} / \mathrm{mmole}$ 
and a molecular weight of 1340 .

Rabbits weighing $1.9-2.6 \mathrm{~kg}$ of both sexes were sacrificed and mesencephalon, diencephalon and spinal cord were minced and homogenized in 9 vol. of ice cold $0.32 \mathrm{M}$ sucrose using a Teflon pestle. The crude mitochondrial $\mathrm{P}_{2}$ fraction was prepared by the method of Segawa and Kuruma (9). Electron microscopic examination revealed that the fraction was composed of intact synaptosomes, myelin and mitochondria (10). The fraction was suspended in modified Krebs-Ringer solution bubbled with $95 \% \mathrm{O}_{2}-5 \% \mathrm{CO}_{2}$ for $10 \mathrm{~min}$. This solution was composed of $118 \mathrm{mM} \mathrm{NaCl}, 4.7 \mathrm{mM} \mathrm{KCl}, 1.9 \mathrm{mM} \mathrm{CaCl}_{2}, 0.5 \mathrm{mM} \mathrm{MgCl}$, $25.0 \mathrm{mM} \mathrm{NaHCO}$ and $11.1 \mathrm{mM}$ glucose. The suspension $(0.7-1.5 \mathrm{mg}$ protein/ml) was divided into $0.9 \mathrm{ml}$ units, each of which was transferred into $10 \mathrm{ml}$ polyethylene tubes. After pre-incubation for $10 \mathrm{~min}$ at $37^{\circ} \mathrm{C}, 0.1 \mathrm{ml}$ of ${ }^{3} \mathrm{H}$-substance $\mathrm{P}$ (final concentration $2.3 \times 10^{-8}-2.3 \times 10^{-6} \mathrm{M}$ ) was added and a further incubation was carried out at $37^{\circ} \mathrm{C}$ for intervals varying from 1 to $20 \mathrm{~min}$. At the end of the incubation period, $6 \mathrm{ml}$ of the cold saline were added to the reaction mixture and centrifugation at $11,500 \times \mathrm{g}$ was carried out for 20 min at $4{ }^{\circ} \mathrm{C}$ after which the supernatant fluid was decanted. The pellet of the fraction was resuspended in $6 \mathrm{ml}$ of the cold saline and was re-centrifuged at $11,500 \times \mathrm{g}$ for $20 \mathrm{~min}$. The washing was repeated. The residual radioactivity in the final washing was found to be essentially negligible. A $0.1 \mathrm{ml}$ portion of $1 \mathrm{~N} \mathrm{NaOH}$ solution was added to the pellet, incubation was carried out at $37^{\circ} \mathrm{C}$ for $30-60 \mathrm{~min}$ and the preparation was then left overnight. After neutralization with $0.1 \mathrm{ml}$ of $1 \mathrm{~N} \mathrm{HCl}$ solution, radioactivity was determined in $10 \mathrm{ml}$ of Bray's solution by a Packard Tri-Carb liquid scintillation counter. Counting efficiency was $20-25 \%$. The protein was estimated by the Folin reagent method of Lowry et al. (11)

The results are presented in Table 1 . When crude mitochondrial $P_{2}$ fraction was incubated with ${ }^{3} \mathrm{H}$-substance $\mathrm{P}$ for 1 or $10 \mathrm{~min}$, substance $\mathrm{P}$ was to some extent taken up into the fraction. However, since the fraction took up almost the same amount of substance $P$

TABLE 1. Uptake of ${ }^{3} \mathrm{H}$-substance $\mathrm{P}$ into crude mitochondrial $\mathrm{P}_{2}$ fraction from rabbit brain and spinal cord

\begin{tabular}{|c|c|c|c|c|c|c|c|}
\hline $\begin{array}{l}\text { Concentra- } \\
\text { tion of }{ }^{3} \mathrm{H}- \\
\text { substance } \mathrm{P} \\
\text { (M) }\end{array}$ & $\begin{array}{l}\text { Incuba- } \\
\text { tion time } \\
\text { (min) }\end{array}$ & $\begin{array}{l}\text { Mesencephalon } \\
\text { cpm/mg protein } \\
\left(37^{\circ} \mathrm{C}-4^{\circ} \mathrm{C}\right)\end{array}$ & $\mathrm{P} / \mathrm{M}^{*}$ & $\begin{array}{l}\text { Diencephalon } \\
\text { cpm/mg protein } \\
\left(37^{\circ} \mathrm{C}-4^{\circ} \mathrm{C}\right)\end{array}$ & $\mathrm{P} / \mathrm{M}^{*}$ & $\begin{array}{l}\text { Spinal cord } \\
\text { cpm/mg protein } \\
\left(37^{\circ} \mathrm{C}-4^{\circ} \mathrm{C}\right)\end{array}$ & $\mathrm{P} / \mathrm{M}^{*}$ \\
\hline \multirow[t]{2}{*}{$2.3 \times 10^{-6}$} & 1 & $1499(3)$ & 0.07 & - & - & $4317(3)$ & 0.20 \\
\hline & 10 & 5231 (3) & 0.24 & - & - & $0(3)$ & 0.00 \\
\hline \multirow[t]{2}{*}{$2.3 \times 10^{-7}$} & 1 & $569(3)$ & 0.27 & - & - & - & -- \\
\hline & 10 & $963(3)$ & 0.45 & - & - & - & - \\
\hline \multirow[t]{2}{*}{$2.3 \times 10^{-8}$} & 1 & $51(3)$ & 0.24 & $88(1)^{* *}$ & 0.41 & $131(1)$ & 0.61 \\
\hline & 10 & $212(3)$ & 0.99 & $217(1)$ & 1.02 & $0(1)$ & 0.00 \\
\hline $2.3 \times 10^{-6}$ & 1 & 5394 (3) & 0.25 & - & - & $0(1)$ & 0.00 \\
\hline (3 $\mathrm{mM} \mathrm{ATP})$ & 10 & $3390(3)$ & 0.16 & - & --- & $0(1)$ & 0.00 \\
\hline
\end{tabular}

Figures in parentheses indicate number of observations. 
both at $4{ }^{\circ} \mathrm{C}$ and $37^{\circ} \mathrm{C}$, the net uptake at $37^{\circ} \mathrm{C}$, calculated by subtracting the value at $4^{\circ} \mathrm{C}$ from the value at $37^{\circ} \mathrm{C}$ was very small or nil. Thus, the pellet/medium ratio, calculated from the net uptake at $37^{\circ} \mathrm{C}$ scarcely exceeded 1 . The uptake was not enhanced either by prolonging incubation time to $20 \mathrm{~min}$ or by adding $3 \mathrm{mM}$ ATP.

In order to differentiate between uptake of ${ }^{3} \mathrm{H}$-substance $\mathrm{P}$ into myelin, synaptosomes and mitochondria, crude mitochondrial $\mathrm{P}_{2}$ fraction incubated with ${ }^{3} \mathrm{H}$-substance $\mathrm{P}\left(10^{-6} \mathrm{M}\right)$ was further separated by means of a discontinuous sucrose density gradient according to the method of Gray and Whittaker (12). The results in Fig. 1 show that uptake of ${ }^{8} \mathrm{H}$ substance $\mathrm{P}$ was predominantly located in mitochondria. For comparison, crude mitochondrial $P_{2}$ fraction from rabbit spinal cord was incubated with ${ }^{14} \mathrm{C}$-glycine $\left(10^{-6} \mathrm{M}\right)$, a candidate for inhibitory transmitter in the spinal cord. As is shown in Fig. 1, the highest concentration was found in synaptosomes.
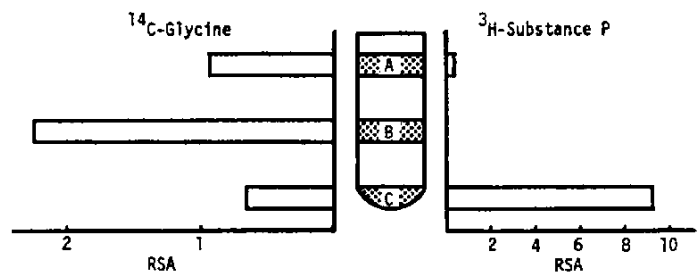

Fig. 1. Uptake of ${ }^{3} \mathrm{H}$-substance $\mathrm{P}$ and ${ }^{14} \mathrm{C}$-glycine into myelin (A), synaptosomes (B) and mitochondria $(C)$ from rabbit diencephalon and spinal cord Crude mitochondrial $\mathbf{P}_{2}$ fraction from diencephalon and spinal cord was incubated for $10 \mathrm{~min}$ at $37^{\circ} \mathrm{C}$ with ${ }^{3} \mathrm{H}$-substance $\mathrm{P}\left(10^{-6} \mathrm{M}\right)$ and ${ }^{14} \mathrm{C}$-glycine $\left(10^{-6} \mathrm{M}\right)$, respectively. Subfractions were then prepared according to the discontinuous sucrose density gradient method of Gray and Whittaker (12).

$\operatorname{RSA}-\frac{\% \operatorname{cpm}\left(37^{\circ} \mathrm{C}-4^{\circ} \mathrm{C}\right)}{\% \text { protcin }}$

It is improbable that during a 10 min incubation a great deal of metabolism of ${ }^{3} \mathrm{H}$ substance $\mathbf{P}$ took place because Benuck and Marks (3) demonstrated that when substance $P$ was incubated with $100,000 \times g$ supernatant of rat brain homogenates only a small amount of arginine, phenylalanine, leucine and methionine was released during $10 \mathrm{~min}$.

In summary, uptake of substance $P$ into crude mitochondrial $P_{2}$ fraction differs from that of known putative transmitters in a number of ways: 1) The amount of substance $P$ taken up into the fraction at $37^{\circ} \mathrm{C}$ was almost the same as that taken up at $0^{\circ} \mathrm{C}$. 2) The pellet/medium ratio, calculated from the net uptake at $37^{\circ} \mathrm{C}$ scarcely exceeded 1.3$)$ The uptake took place predominantly in mitochondria, not in synaptosomes.

These results suggest that the uptake is passive diffusion or non-specific binding rather than the high affinity transport. Further studies are underway to determine whether similar results can be obtained in small regions of the brain or spinal cord that are enriched in substance $\mathbf{P}$.

Acknowledgements: This work was supported in part by Grant No. 048201 for the research of science from the Department of Education, Japan. Thanks are due to the staff 
of Shinloihi Co., Ltd., Kamakura, Japan for irradiation of substance P, and Sumitomo Chemical Co., Takarazuka, Japan, for aid in purifying ${ }^{3} \mathrm{H}$-substance $\mathrm{P}$.

\title{
REFERENCES
}

1) Leeman, S.E. and Mroz, E.A.: Life Sci. 15, 2033 (1974): 2) Takahashi, T., Konishi, S., Powell, D., Leeman, S.E. and Otsuka, M.: Brain Res. 73, 59 (1974); 3) Benlck, M. AND Marks, N.: Biochem. biophys. Res. Commun. 65, 153 (1975); 4) Bernett, J.P., Mulder, A.H. and SNYder, S.H.: Life Sci. 15, 1045 (1974); 5) Yajima, H., Kitagawa, K. and Segawa, T.: Chem. Pharm. Bull. 21, $2500(1973)$; 6) Meshi, T. aNd TAKahashi, T.: Bull. chem. Soc. Japan 35, 1510 (1962); 7) Meshi, T. axd Sato, Y.: Bull. chem. Soc. Japan 37, 683 (1964): 8) Gray, W.R. And Hartley, B.S.: Biochem. J. 89, 59P (1963); 9) Segawa, T. and Kuruma, I.: J. Pharm. Pharmacol. 20, 320 (1968); 10) Segawa, T., Kuruma, I., Takatsuka, K. and Takagi, H.: Folia pharmacol. japon. 66, 400 (1970) (in Japanese); 11) Lowry, O.H., Rosebrougli, N.J., Farr, A.L. and Randall, R.J. : $J$. biol. Chem. 193, 265 (1951); 12) Gray, E.G. and Whittakfr. V.P.: J. Anat., Lond. 96, 79 (1962)

\section{PROTECTIVE EFFECT OF SODIUM POLYACRYLATE ON INDUCED DUODENAL ULCERATION IN GUINEA PIGS}

\author{
Ei-ichi KOKUE and Yuji TAKAHASHI \\ Tokyo University of Agriculture and Technology, Faculty of Agriculture, \\ Department of Veterinary Science, Saiwai-cho, Fuchu-shi, Tokyo 183, Japan
}

Accepted July 14, 1976

Sodium polyacrylate (PAS) which is used as a food additive is a high molecular polyanion and its water solution is highly viscous. We reported previously that PAS protected the experimental gastric ulceration in rats $(1,2)$ and have pointed out in reports that the agent has several promising properties regarding the prevention and treatment of gastric ulcerations. The present study was undertaken to evaluate the inhibitory effect of PAS against the experimental duodenal ulceration in guinea pig. Alminium Silicate (AI. Si), an antacid, was employed as a positive control drug.

Duodenal ulceration was produced in guinea pigs by a modification of the method of Anderson and Watt (3). Guinea pigs, weighing 400-500 gm, were fasted for $24 \mathrm{hr}$, but allowed water ad libitum. Six aqueous solutions containing PAS or Al.Si, 1.25, 2.5 and $5.0 \mathrm{~g} / \mathrm{dl}$ were prepared. Ten $\mathrm{ml}$ of the solution was given intragastrically once a day for two days. The control group was given the same volume of saline. On days 1 and 2 each animal was given promethazine hydrochloride $10 \mathrm{mg} / \mathrm{kg}$ (s.c.) one hr after the administration of the test substance, followed by a dose of histamine (free base) $10 \mathrm{mg} / \mathrm{kg} \mathrm{s.c.} \mathrm{suspended} \mathrm{in}$ beeswax and mineral oil with a interval of $30 \mathrm{~min}$. The animals were sacrificed $24 \mathrm{hr}$ after the 2 nd histamine injection. The duodenum was removed and the degree of damage was assessed numerically. The severity of the lesion was classified into three gradations: small ulcer (less than $3 \mathrm{~mm}$ in diameter), large ulcer (more than $3 \mathrm{~mm}$ ) and perforated ulcer. 